\title{
New Pharmacological Treatments for Dry Eye Disease
}

\author{
Gary D. Novack
}

Published online: 6 March 2013

(c) Springer Science + Business Media New York 2013

\begin{abstract}
The impact of dry eye disease on patient's health, visual function and quality of life may be substantial. At present, the only approved pharmacological treatment in the U.S. or Canada is Restasis ${ }^{\circledR}$ (cyclosporine ophthalmic emulsion). In Japan, three products are approved: Hyalein ${ }^{\circledR}$ (hyaluronic acid), Diquas ${ }^{\circledR}$ (diquafasol), and Mucosta $^{\circledR}$ (rebamapide). No pharmacological treatment is currently approved in Europe. In this article, I will provide updates on "new" pharmacological treatments-i.e., those beyond any approved as of January 2012, primarily those in clinical trials. Novel treatment for pharmacological management of dry eye disease is an area of active clinical development as evidenced by numerous recently completed or ongoing studies. The pharmacological agents in evaluation cover a wide range of putative mechanisms of action. However, firms developing these agents continue to be challenged by the limitations of animal models of efficacy, relatively small and variable clinical effects in Phase 2, and the investment in time and resources required for Phase 3.
\end{abstract}

Keywords Dry eye Keratoconjunctivitis sicca . Regulatory agencies $\cdot$ Pharmacology

\section{Introduction}

The impact of dry eye disease on patient's health, visual function and quality of life may be substantial, as discussed in the Dry Eye Workshop (DEWS) in 2007 [1]. Like ocular

G. D. Novack $(\bowtie)$

PharmaLogic Development, Inc., 17 Bridgegate Drive,

San Rafael, CA 94903, USA

e-mail: gary_novack@pharmalogic.com surface disease itself, management and therapy is complex and multifactorial. The Management and Therapy Subcommittee of DEWS recommended a staged, additive approach to management, depending upon the severity of the disease and the response to treatments. The categories of pharmacological treatments included artificial tear substitutes, gels and ointments (regulated by the U.S. FDA under the over-the-counter ophthalmic monograph, 21 CFR 349) [2, 3], anti-inflammatory agents (topical cyclosporine and corticosteroids and oral omega-3 fatty acids), secretagogues, serum, and systemic immunosuppressives [4•]. The regulatory issues in developing and approving ocular pharmacological treatments for dry eye was reviewed at a tear film and ocular surface (TFOS)/ Association for Research in Vision and Ophthalmology (ARVO) symposium. As of January 2012, the only approved pharmacological treatment in the U.S. or Canada is Restasis ${ }^{\circledR}$ (cyclosporine ophthalmic emulsion). In Japan, three products are approved: Hyalein ${ }^{\circledR}$ (hyaluronic acid), Diquas ${ }^{\circledR}$ (diquafasol), and Mucosta ${ }^{\circledR}$ (rebamapide). No pharmacological treatment is currently approved in Europe [5•].

In this article, I will provide updates on "new" pharmacological treatments-i.e., those beyond any approved as of January 2012, primarily those in clinical trials. This information is current as of 30 November 2012. I sought full papers on this topic in ophthalmology journals and MEDLINE. However, there seems to be a lag between conduct of these studies and full publication. Thus, I used the following additional sources:

- Internet based clinical trial registries: www.clinicaltrials.gov, www.clinicaltrialsregister.eu/, www.clinicaltrials.jp for the phrase "dry eye" or "sicca". Note that the law and practice of clinical trial registration varies by country $[6,7]$.

- United States Patent database: (http://www.uspto.gov/) for patents issued between 1 January 2005 and 30 
November 2012 containing the words "dry eye" or "sicca" in the title. (Patents issued between 1 January 2002 and 31 December 2004 may be found in a previously published article) [8].

- Corporate press releases and presentations of which I am aware.

None of these sources is absolutely inclusive. While I have made best efforts to be thorough, it is possible that the above approaches missed some therapies. Also, sponsors do not always notify the public when a particular product is no longer under active development. Small companies in particular must raise funds frequently in order to pay the costs of development. There is one final caveat-the use of the clinical development phase is a continuum, not an absolute, and thus may not correctly and unambiguously describe the development stage [9].

\section{Clinical Trial Registries}

Clinicaltrials.gov (U.S. based) has 246 studies meeting the criteria of "dry eye" or "sicca" (135 of which are in the U.S., 27 are in China and 15 are in Japan). Of these 246 studies, 37 are currently "open" (meaning recruiting, not yet recruiting, or unknown). Further refining to those started in 2010 or later (my definition of "new"), and limiting to studies on pharmacological agents, there are 42. The European registry had 18 studies meeting the criteria, of which 6 met the further refinement. The Japanese registry had 12 studies meeting the criteria, of which 3 met the further refinement. There is some cross-registration of studies on different on-line registries, which is consistent with the guidances. Entries are not always current, and thus "conducting" versus "conducted" is a matter of judgment for the user. I used the organizational schema from the DEWS report [4•], with the category of "other" for those agents for which the mechanism of action or clinical effects are not yet well known.

\section{Artificial Tears Substitutes}

- Hyaluronic acid in various formulations continues to be evaluated by many firms including Alcon, River Plate, and Seikagaku (SI-614). This agent has the rare position of being regulated in the U.S. as a drug, a device, or an excipient, depending upon the product.

Anti-Inflammatory Agents

- Alcon conducted a Phase 2 study of Durezol ${ }^{\circledR}$ (difluprednate).
- Allergan evaluated a new formulation of cyclosporine.

- Bausch + Lomb conducted a Phase 2 study of BOL303242-X Ophthalmic Suspension, a novel selective glucocorticoid receptor agonist (SEGRA) [10].

- EyeGate conducted two studies evaluating dexamethasone as applied by iontophoresis. They announced that they are now seeking other posterior segment indications.

- InSite Vision is planning a Phase 2 study of ISV-101 (bromfenac in DuraSite ${ }^{\mathrm{TM}}$ vehicle).

- ISTA (now part of Bausch + Lomb) conducted a Phase 3 study of bromfenac.

- Novagali has conducted a study of NOVA22007, a proprietary formulation of cyclosporine.

- Santen has conducted a Phase 2 study of DE-110 (a SEGRA).

- SARCode has completed several studies, including a Phase 3 study, of SAR 1118 (lifitegrast), an inhibitor of lymphocyte function-associated antigen (LFA-1) [11•, 12, 13] and has a safety trial ongoing. The firm announced plans for a second Phase 3 study.

- Sirion has completed a study of ST-603-005, a proprietary formulation of cyclosporine.

- The Wenzhou Medical College is conducting a study of two different non-steroidal anti-inflammatory agents and fluorometholone.

Secretogogues

- Otsuka and Acucela are co-developing rebamapide (OPC-12759). Several studies have been conducted, and it appears that there is a Phase 3 study ongoing in the U.S. and an additional safety study ongoing in Japan.

- Santen has conducted additional studies of diquafasol (DE-089).

Serum

- Chonman and Fundacion Imabis each conducted a study of autologous serum and umbilical cord serum.

Others

- Alcon conducted a study with ESBA105, an antibody fragment therapeutic with anti-tumor necrosis factor (TNF) activity, in the treatment of dry eye.

- Bitop is planning a study of Ectoin containing ophthalmic solution (a derivate of an amino acid found in extremophilic microorganisms). 
Table 1 List of U.S. Patents issued between 1 January 2005 and 30 November 2012 containing the words "dry eye" or "sicca" in the title

\begin{tabular}{|c|c|c|c|c|}
\hline $\begin{array}{l}\text { US Patent } \\
\text { number }\end{array}$ & Title & First author & Assignee & $\begin{array}{l}\text { Date of } \\
\text { issuance }\end{array}$ \\
\hline $6,872,382$ & Use of selective PDE IV inhibitors to treat dry eye disorders & Gamache & Alcon & $\begin{array}{l}29 \text { March } \\
2005\end{array}$ \\
\hline $6,872,383$ & Use of macrolide compounds for the treatment of dry eye & Ueno & Sucampo & $\begin{array}{l}29 \text { March } \\
2005\end{array}$ \\
\hline $6,874,884$ & Remedy for dry eye syndrome & Schwebel & - & 3 April 2005 \\
\hline $6,886,933$ & Remedy for dry eye syndrome & Schwebel & - & 3 May 2005 \\
\hline $6,887,858$ & Method of treating dry eye disease with purinergic receptor agonists & Yerxa & Inspire & 3 May 2005 \\
\hline $6,921,755$ & Method of treating dry eye disease with purinergic receptor agonists & Yerxa & Inspire & 26 July 2005 \\
\hline $7,026,296$ & Methods of treating dry eye disorders & Gamache & Alcon & 11 April 2006 \\
\hline $7,029,712$ & Treatment for dry eye syndrome & Thornton & - & 18 April 2006 \\
\hline $7,036,928$ & Remedy for dry eye syndrome & Schwebel & - & 2 May 2006 \\
\hline $7,060,728$ & $\begin{array}{l}\text { 11,12-Oxidoarachidonic acid derivatives and methods of their use in } \\
\text { treating dry eye disorders }\end{array}$ & Belanger & Alcon & $\begin{array}{l}6 \text { February } \\
2004\end{array}$ \\
\hline $7,063,857$ & Use of macrolide compounds for the treatment of dry eye & Ueno & Sucampo & 20 June 2006 \\
\hline $7,112,588$ & Use of proteasome inhibitors to treat dry eye disorders & Klimko & Alcon & $\begin{array}{l}26 \text { September } \\
2006\end{array}$ \\
\hline $7,186,233$ & Dry eye treatment & Dohlman & $\begin{array}{l}\text { Massachusetts Eye \& } \\
\text { Ear Infirmary }\end{array}$ & 6 March 2007 \\
\hline $7,189,697$ & $\begin{array}{l}\text { Compositions and uses of a galectin for treatment of dry eye } \\
\text { syndrome }\end{array}$ & Panjwani & Tufts College & $\begin{array}{l}13 \text { March } \\
2007\end{array}$ \\
\hline $7,204,995$ & $\begin{array}{l}\text { Treatment and control of dry eye by use of biodegradable polymer } \\
\text { capsules }\end{array}$ & El-Sherif & - & 17 April 2007 \\
\hline $7,223,737$ & Method of treating dry eye disorders using glycosides & $\mathrm{Ke}$ & Alcon & 29 May 2007 \\
\hline $7,231,922$ & $\begin{array}{l}\text { Apparatus, system and method for treating dry eye conditions and } \\
\text { promoting healthy eyes }\end{array}$ & Davison & - & 19 June 2007 \\
\hline $7,235,556$ & Methods of treating dry eye disorders & Sharif & Alcon & 26 June 2007 \\
\hline $7,247,623$ & Method of treating dry eye disease with non-drying antihistamines & Yerxa & Inspire & 24 July 2007 \\
\hline $7,321,000$ & $\begin{array}{l}\text { Ophthalmic composition containing } \mathrm{N} \text {-acetyl-cysteine for the } \\
\text { treatment of dry eye syndrome }\end{array}$ & Boldrini & Farmigea & $\begin{array}{l}22 \text { January } \\
2008\end{array}$ \\
\hline $7,357,500$ & Remedy for dry eye syndrome & Schwebel & - & 15 April 2008 \\
\hline $7,381,707$ & Treatment of dry eye & Lin & Johnson \& Johnson & 3 June 2008 \\
\hline $7,459,441$ & Remedies for dry eye and diseases associated with dry eye & Minagawa & Senju, Itoham Foods & $\begin{array}{l}2 \text { December } \\
2008\end{array}$ \\
\hline $7,638,142$ & Therapeutic composition for the treatment of dry eye syndrome & Krawitz & Vitamin Science & $\begin{array}{l}29 \text { December } \\
2009\end{array}$ \\
\hline $7,691,811$ & $\begin{array}{l}\text { Transporter-enhanced corticosteroid activity and methods and } \\
\text { compositions for treating dry eye }\end{array}$ & Bodor & - & 6 April 2010 \\
\hline $7,745,461$ & Method of treating dry eye disorders & Klimko & Alcon & 29 June 2010 \\
\hline $7,759,322$ & Method of treating dry eye disease with purinergic receptor agonists & Yerxa & Inspire & 20 July 2010 \\
\hline $7,825,102$ & Treatment of dry eye conditions & Fishman & Can-Fite & $\begin{array}{l}2 \text { November } \\
2012\end{array}$ \\
\hline $7,897,642$ & Compositions and methods for dry eye syndrome & Dubow & - & 1 March 2011 \\
\hline $7,923,471$ & Method of treating dry eye disorders and uveitis & Klimko & Alcon & 12 April 2012 \\
\hline $8,114,420$ & $\begin{array}{l}\text { Composition for treating dry eye and related methods of manufacture } \\
\text { and methods of use }\end{array}$ & Xia & Bausch \& Lomb & $\begin{array}{l}14 \text { February } \\
2012\end{array}$ \\
\hline $8,207,226$ & Use of FAAH antagonists for treating dry eye and ocular pain & Gadd & Alcon & 26 June 2012 \\
\hline $8,211,434$ & KLK-13 antibody inhibitor for treating dry eye & Stern & Allergan & 3 July 2012 \\
\hline $8,211,942$ & Compositions and methods for dry eye syndrome & Dubow & - & 3 July 2012 \\
\hline $8,293,713$ & Beta-turn peptidomimetic cyclic compounds for treating dry eye & Cumberlidge & Mimetogen & $\begin{array}{l}23 \text { October } \\
2012\end{array}$ \\
\hline $8,314,118$ & Methods and compositions for treating dry eye & Zagon & - & 15 April 2012 \\
\hline
\end{tabular}


- Can-Fite is conducting a Phase 3 study with oral CF101 (IB-MECA).

- CT Development (who acquired rights from Resolvyx) is conducting a Phase 2 study of RX-10045 (a synthetic resolvin).

- Dong is conducting a Phase 2 study of DA-6034 eyedrops, a flavonoid derivative.

- Kissei completed a Phase 2 study of KLS-0611 and of KCT-0809 (ozagrel, a thromboxane A2 synthase inhibitor), and is planning additional studies of KCT-0809.

- Mimetogen conducted a Phase 2 study of MIM-D3, a growth factor mimetic.

- Novartis completed a study of AIN457 (secukinumab, a human anti-IL-17A monoclonal antibody) and ACZ885 (a fully human monoclonal antibody that inhibits IL-1 beta).

- Pfizer conducted early phase studies on tofacitinib (CP-690,550), a Janus kinase inhibitor, in patients in Japan and the U.S. [14].

- Rigel is planning a study of R-348 Ophthalmic Solution, a JAK-kinase inhibitor.

- Santen has conducted studies of DE-101, a topical ophthalmic suspension of rivoglitazone, a novel peroxisome proliferator-activated receptor (PPAR) gamma agonist used orally for the treatment of diabetes.

- Sylentis has completed a Phase 1 study of Drug: SYL1001, a form of interference RNA (RNAi) which inhibits the capsaicin receptor TrpV1.

- The Medical University of Vienna has completed a Phase 1 study of chitosan-N-acetylcysteine and is planning an additional study.

- The Medical University of Vienna is planning a study of a dietary supplement including Vitamin A.

- Thymosin Beta 4 was evaluated by RegeneRx in a completed study, and Michigan Cornea Consultants is currently conducting a study on this agent.

- Zea vision is conducting a study of a dietary supplement including Omega 3, Vitamins A, D3 and E.

\section{Patents}

Using the criteria, there were 36 patents that met the criteria for the approximate 7 years (Table 1). In a previous review of patents issued in the preceding 3 years, most $(15 / 23)$ were assigned to Alcon, and three apparently covered products that were either marketed or in clinical development [8]. In this current period, $25 \%$ (9/36) patents were assigned to Alcon, $11 \%$ to Inspire, and $6 \%$ to
Sucampo. As well, $31 \%$ were to seemingly "independent" inventors. These patents also apparently cover at least one marketed product. An issued patent does not guarantee that the product named will be commercialized, or when or if it will be marketed. Patents may be either a leading or a trailing indicator of clinical development.

\section{Other Sources}

- Eleven Biotherapeutics is developing EBI-005, is a novel interleukin-1 (IL-1) receptor antagonist protein therapeutic for topical delivery to the eye for the treatment of ocular surface disease. An IND was filed in late 2012.

- Parion Sciences has evaluated novel topically applied epithelial sodium channel inhibitors on tear production in mice, suggesting that they have an interest in this area [15].

\section{Conclusion}

Novel treatment for pharmacological management of dry eye disease is an area of active clinical development as evidenced by numerous recently completed or ongoing studies. The multifactorial nature of the disease continues to result in multiple approaches to its management. The pharmacological agents in evaluation cover a wide range of putative mechanisms of action. Firms developing these agents continued to be challenged by the limitations of animal models of efficacy, relatively small and variable clinical effects in Phase 2, and the investment in time and resources required for Phase 3 . With only a few ocular pharmacological agents approved worldwide, precedents are few and vary by country, requiring even larger and more complicated development plans to meet the worldwide need.

Disclosure G. Novack is a consultant for Acucela and Mimetogen, and serves as a consultant to numerous other pharmaceutical and medical device firms in the development of products.

\section{References}

Papers of particular interest, published recently, have been highlighted as:

- Of importance

1. Foulks GN. DEWS report: a mission completed. Ocul Surf. 2007;5(2):65-6.

2. Anonymous: Ophthalmic drug products for over-the-counter human use; final monograph. Fed Reg 1988;53(43):7076-7093. 
3. Novack GD. Pipeline: how are tear lubricant products regulated in the US? Ocul Surf. 2003;1(2):86.

4. - Pflugfelder SC, Geerling G, Kinoshita S, Lemp MA, McCulley J, Nelson D, Novack GD, Shimazaki J, Wilson C: Management and therapy of dry eye disease: Report of the Management and Therapy Subcommittee of the International Dry Eye WorkShop (2007). Ocul Surf 2007;5(2):163-178. This part of the Dry Eye Workshop (DEWS) report gives then current consensus on disease management and therapy.

5. - Sullivan DA, Hammitt KM, Schaumberg DA, Sullivan BD, Begley CB, Gjorstrup P, Garrigue J-S, Nakamura M, Quentric Y, Barabino S, Dalton M, Novack GD: Report of the TFOS/ARVO symposium on global treatments for dry eye disease: an unmet need. Ocul Surf 2012;10(2):108-116. These proceedings of a regulatory symposium held just prior to the TFOS meeting in 2010 give a good view of the current worldwide regulatory status of novel pharmacological therapies.

6. Novack GD. Pipeline: clinical trial registration. Ocul Surf. 2007;54(4):62-4.

7. Novack GD. Pipeline: clinical trial registry-update. Ocul Surf. 2009;7(4):212-4.

8. Novack GD. Pipeline: recent patents in dry eye. Ocul Surf. 2005;3(2):115-6.

9. Anonymous: International conference on harmonisation; draft guidelines on general considerations for clinical trials. Fed Reg 1997;62(104):29543.

10. Zhang JZ, Cavet ME, Vandermeid KR, Salvador-Silva M, Lopez FJ, Ward KW. BOL-303242-X, a novel selective glucocorticoid receptor agonist, with full anti-inflammatory properties in human ocular cells. Mol. Vis. 2009;15:2606-16.

11. - Gadek TR, Burdick DJ, McDowell RS, Stanley MS, Marsters JC, Jr., Paris KJ, Oare DA, Reynolds ME, Ladner C, Zioncheck KA, Lee WP, Gribling P, Dennis MS, Skelton NJ, Tumas DB, Clark KR, Keating SM, Beresini MH, Tilley JW, Presta LG, Bodary SC: Generation of an LFA-1 antagonist by the transfer of the ICAM-1 immunoregulatory epitope to a small molecule. Science. 2002;295(5557):1086-1089. Key paper on the proposed mechanism of SAR-1118 (lifitegrast).

12. Semba CP, Swearingen D, Smith VL, Newman MS, O'Neill CA, Burnier JP, Haughey DB, Gadek TR. Safety and pharmacokinetics of a novel lymphocyte function-associated antigen-1 (LFA1) antagonist ophthalmic solution (SAR 1118) in healthy adults. J Ocul Pharmacol Ther. 2010;27(1):99-104.

13. Semba CP, Torkildsen GL, Lonsdale JD, McLaurin EB, Geffin JA, Mundorf TK, Kennedy KS, Ousler GW. A Phase 2 randomized, double-masked, placebo-controlled study of a novel integrin antagonist (SAR 1118) for the treatment of dry eye. Am J Ophthalmol. 2012;153(6):1050-60.

14. Liew SH, Nichols KK, Klamerus K, Li JZ, Zhang M, Foulks GN. Safety and efficacy of topical ophthalmic CP-690,550, a janus kinase inhibitor, for dry eye disease: a phase $1 / 2$ clinical trial [abstract]. ARVO Meeting Abstracts. 2011;52:4246.

15. Thelin WR, Johnson MR, Hirsh AJ, Kublin CL, Zoukhri D. Effect of topically applied epithelial sodium channel inhibitors on tear production in normal mice and in mice with induced aqueous tear deficiency. J Ocul Pharmacol Ther. 2012;28(4):433-8. 